\title{
EL JUICIO MONITORIO EN ESPAÑA TRAS LAS ÚLTIMAS REFORMAS PROCESALES
}

\section{The monitory procedure in Spain after the latest procedural reforms}

\author{
Esther González Pillado*
}

\begin{abstract}
Resumen: Desde la introducción en España del juicio monitorio por la Ley 1/2000, de 7 de enero, de Enjuiciamiento Civil, en sus diez años de vigencia se ha convertido en el procedimiento más utilizado en el ámbito civil por los operadores jurídicos (el 61\% de los asuntos civiles tramitados fueron juicios monitorios). La razón de esta utilización masiva se debió a su propia configuración procedimental, en cuanto ofrece una protección ágil y rápida del derecho de crédito del acreedor. De este modo, presentada la petición monitoria junto con una mínima base documental y una vez que el deudor es requerido de pago, el acreedor podrá demandar la satisfacción de la cantidad reclamada o bien el despacho de ejecución, y sólo cuando el deudor alegue una causa de oposición podrá ponerse término al juicio monitorio y se transformará en un juicio declarativo ordinario por la cuantía.

Ahora bien, durante los años de vigencia de la ley el legislador ha sido consciente de la necesidad de reformar el juicio monitorio para, en unos casos, aclarar algunas dudas que su aplicación práctica estaba generando y, en otros, aumentar su eficacia. Estas reformas son objeto de análisis en este trabajo.
\end{abstract}

Palabras clave: Juicio monitorio - requerimiento de pago - despacho de ejecución oposición - juicio declarativo ordinario.

Abstract: Since the introduction of the monitory procedure in Spain by the Law 1/2000 of 7 January of Civil Procedure, it has become the most widely used procedure in the civil process law by the legal actors ( $61 \%$ of the civil cases were monitory procedures). We can find the reason for this great use in its procedural setting because it gives an agile and fast judicial protection of the creditor's claim. In this way, once the creditor files a lawsuit through the monitory procedure based on sufficient documentary evidence and once the debtor is required for payment, the plaintiff may request either the discharge of the debt or a writ of execution, and only when the debtor raises an objection, the enforcement of the monitory procedure will be ended and transformed into a declaratory action.

However, during this years the legislator has been aware of the need to reform the monitory procedure, in some cases to clarify some doubts that its practical application was generating, and in others, to increase its effectiveness. These amendments are analyzed in this work.

Keywords: Monitory procedure - request for payment - writ of execution - objection declaratory action.

\footnotetext{
* Catedrática de Derecho Procesal de la Universidad de Vigo (España). Correo electrónico: epillado@,uvigo.es.
}

Este artículo fue recibido el 5 de abril del año 2012, siendo aprobada su publicación con fecha 9 de octubre de 2012. 
González - El juicio monitorio en España tras las últimas reformas procesales

\section{Consideraciones previas}

La Ley 1/2000, de 7 de enero, de Enjuiciamiento Civil (en adelante, LEC) introdujo, entre sus múltiples novedades, el juicio monitorio en el ordenamiento procesal español con el objetivo de garantizar una protección rápida y eficaz del crédito dinerario líquido de los justiciables, en especial, los profesionales y pequeños y medianos empresarios. ${ }^{1}$

El juicio monitorio, para alcanzar esa finalidad, se reguló en los arts. 812 a 818 LEC y permite al acreedor de una deuda dineraria, líquida, vencida, exigible, y que esté documentada, solicitar ante el órgano jurisdiccional que requiera de pago al deudor para que éste, en el plazo legalmente establecido (20 días), o bien pague la cantidad reclamada, lo que dará lugar al archivo de las actuaciones; o bien se oponga alegando razones, lo que provocará la transformación del juicio monitorio en el declarativo ordinario que corresponda por razón de la cuantía (juicio ordinario o juicio verbal); finalmente, si el deudor se mantiene inactivo, se despache ejecución por la cantidad reclamada.

La propia configuración del juicio monitorio, que permite evitar el proceso declarativo ordinario, mucho más largo y costoso, ${ }^{2}$ hizo que desde un momento muy inicial de la entrada en vigor de la LEC (enero de 2001), este juicio tuviera una muy buena acogida por los operadores jurídicos, no sólo pequeños empresarios y profesionales, sino que grandes empresas e incluso profesionales para quienes la propia ley procesal ya había previsto un procedimiento especial para la reclamación de sus honorarios. ${ }^{3}$ La buena acogida de este procedimiento se ha visto

\footnotetext{
${ }^{1}$ Apdo. XIX Exposición de Motivos de la LEC.

${ }^{2}$ La disminución del coste del proceso es obvia en cuanto en el juicio monitorio no se exige que la petición inicial se presente por abogado y procurador. La situación varía si existe oposición, pues, una vez que el juicio monitorio termina y se transforma en un ordinario por la cuantía, la intervención de abogado y procurador será necesaria en todo caso en el juicio ordinario (reclamaciones de cuantía superior a 6.000 euros) y en el verbal siempre que la cuantía supere 2.000 euros.

${ }^{3}$ Es el caso de los abogados y procuradores que, en lugar de acudir al procedimiento de jura de cuentas, regulado en los arts. 35 y ss. LEC, han optado en muchas ocasiones por la utilización del juicio monitorio para la reclamación de sus honorarios y derechos frente a sus clientes.

No existe unanimidad en la jurisprudencia a la hora de decantarse sobre la utilización del juicio monitorio para la reclamación de las deudas de abogado y procurador. Así, para un sector jurisprudencial los arts. 34 y 35 LEC establecen el cauce procedimental para tramitar estas reclamaciones, lo que impedirá acudir al monitorio. Así, los AAP de Cáceres, de 26 de noviembre de 2002 (ED 2002/68278); de Las Palmas, de 16 de abril de 2004 (La Ley Juris 1684642/2004); de Guipúzcoa, de 20 de febrero de 2006 (La Ley 2288623/2006).

En sentido contrario, para otro sector jurisprudencial, mayoritario, Ley procesal civil no prohíbe en ninguno de sus preceptos al abogado o procurador la posibilidad de acudir al proceso monitorio para la reclamación de sus honorarios, y tampoco les obliga a acudir al procedimiento de los arts. 34 y 35 LEC, que se prevé como una opción procedimental para el profesional que podrá elegir si lo considera idóneo para la defensa de sus intereses. Entre otros, AAP de Cádiz, de
} 
incrementada en los años siguientes, de tal forma que en el momento actual es el procedimiento más empleado para la reclamación de deudas dinerarias, líquidas, vencidas y documentadas. Valga como muestra de lo señalado que en el año 2001 (primero de la vigencia de la LEC) se plantearon en España 120.165 procedimientos monitorios, cifra que se eleva en 2010 a $845.875 .{ }^{4}$

Esta masiva utilización del juicio monitorio ha llevado a que, en su corta vida, el legislador haya procedido a su reforma en varias ocasiones con el objetivo de aclarar algunas dudas que su aplicación práctica estaba generando, en unos casos, y aumentar su eficacia, en otros. A estas reformas se refieren los apartados siguientes donde se tratará de poner de manifiesto el acierto o desacierto del legislador con su introducción en la LEC.

\section{La reforma operada por la Ley $13 / 2009$, de 3 de noviembre}

La Ley 13/2009, de 3 de noviembre, para la implantación de la Oficina judicial, ${ }^{5}$ ha supuesto una reforma de gran envergadura en el ámbito procesal civil; muestra de ello es que se han reformado 337 artículos de los 827 de que consta la LEC, además de una disposición adicional y otra final. El eje central de esta reforma es la atribución de nuevas competencias al Secretario judicial y las relaciones que éste tiene con el juez en la nueva configuración del proceso. ${ }^{6}$

En efecto, como destaca la propia Exposición de Motivos de la Ley 13/2009, uno de los medios esenciales para conseguir que los ciudadanos dispongan de una Justicia, ágil, transparente, responsable y respetuosa con los valores constitucionales, es la implantación de la Oficina judicial, cuyo objetivo es la racionalización y optimización de los recursos dedicados a la administración de justicia. En este contexto, se trata de que "los Jueces y Magistrados dediquen todos sus esfuerzos a las funciones que les vienen encomendadas por la Constitución: juzgar y hacer ejecutar lo juzgado. Para ello es preciso descargarles de todas aquellas tareas no vinculadas estrictamente a las funciones constitucionales que se acaban de señalar, y a ello tiende el nuevo modelo de la Oficina judicial. En ella, se atribuirán a otros funcionarios aquellas responsabilidades y funciones que no tienen carácter jurisdiccional y, por otra parte, se establecerán sistemas de

14 de diciembre de 2010 (AC 2010/219); de Cádiz, de 22 de septiembre de 2006 (JUR 2007/62577); de Cantabria, de 28 de enero de 2003 (AC 2003/145).

${ }^{4}$ La justicia dato a dato, p. 61, http://www.poderjudicial.es.

Teniendo en cuenta que durante el año 2010 ingresaron en el orden jurisdiccional civil 1.984.098 asuntos, los juicios monitorios representaron un $61 \%$ de la actividad jurisdiccional civil. Panorámica de la Justicia, http://www.poderjudicial.es.

5 Que ha sido complementada por la Ley 1/2009, de 3 de noviembre, que modifica la Ley Orgánica del Poder Judicial (en adelante, LOPJ).

${ }^{6}$ Esta reforma supone un paso más en el camino iniciado por la Ley 19/2003, de 23 de diciembre, que amplió las facultades del Secretario judicial potenciando sus capacidades profesionales en la línea de atribuirle funciones que hasta ese momento eran competencia de los jueces y magistrados. 
González - El juicio monitorio en España tras las últimas reformas procesales

organización del trabajo de todo el personal al servicio de la Administración de Justicia, de forma que su actividad profesional se desempeñe con la máxima eficacia y responsabilidad. En este nuevo diseño, jugarán un papel de primer orden los integrantes del Cuerpo Superior Jurídico de Secretarios judiciales”.

Centrándonos en el juicio monitorio, ese reforzamiento de las competencias del Secretario judicial ha tenido especial intensidad en su tramitación, pero, además, se aprovecha esta reforma para introducir otros cambios en este juicio que tratan de resolver algunos problemas que su aplicación práctica estaba generando en el día a día de los juzgados. A todas estas cuestiones se dedican los apartados siguientes.

\section{a) Redistribución de competencias entre el Secretario judicial y el Juez}

Con carácter previo al análisis de las nuevas funciones que el Secretario judicial ha asumido en el juicio monitorio, es necesario dejar asentadas dos premisas: de un lado, la atribución de nuevas funciones al Secretario judicial no supone, en ningún caso, reducción de garantías para el ciudadano, pues los Secretarios Judiciales forman un cuerpo técnico con formación especializada que les cualifica suficientemente para su desempeño; pero además, todas las resoluciones del Secretario judicial podrán ser controladas por el Juez a través, no sólo de la declaración de nulidad, sino también con el nuevo recurso de revisión introducido, por esta misma Ley 13/2009, en el art. 454 bis LEC. $^{8-9}$

\footnotetext{
7 Apartado I de la Exposición de Motivos Ley 13/2009.

${ }^{8}$ Artículo 454 bis. LEC. Recurso de revisión.

1. Contra el decreto resolutivo de la reposición no se dará recurso alguno, sin perjuicio de reproducir la cuestión al recurrir, si fuere procedente, la resolución definitiva. Esta reproducción se efectuará, necesariamente, en la primera audiencia ante el Tribunal tras la toma de la decisión y, si no fuera posible por el estado de los autos, se podrá solicitar antes de que se dicte la resolución definitiva para que se solvente en ella.

Cabrá recurso directo de revisión contra los decretos por los que se ponga fin al procedimiento o impidan su continuación. Dicho recurso carecerá de efectos suspensivos sin que, en ningún caso, proceda actuar en sentido contrario a lo que se hubiese resuelto.

Cabrá interponer igualmente recurso directo de revisión contra los decretos en aquellos casos en que expresamente se prevea.

2. El recurso de revisión deberá interponerse en el plazo de cinco días mediante escrito en el que deberá citarse la infracción en que la resolución hubiera incurrido. Cumplidos los anteriores requisitos, el Secretario judicial, mediante diligencia de ordenación, admitirá el recurso concediendo a las demás partes personadas un plazo común de cinco días para impugnarlo, si lo estiman conveniente.

Si no se cumplieran los requisitos de admisibilidad del recurso, el Tribunal lo inadmitirá mediante providencia.

Transcurrido el plazo para impugnación, háyanse presentado o no escritos, el Tribunal resolverá sin más trámites, mediante auto, en un plazo de cinco días.

Contra las resoluciones sobre admisión o inadmisión no cabrá recurso alguno.

3. Contra el auto dictado resolviendo el recurso de revisión sólo cabrá recurso de apelación cuando ponga fin al procedimiento o impida su continuación.
} 
De otro lado, tampoco esa atribución de nuevas competencias al Secretario judicial se puede entender como contraria al art. 117 Constitución Española (CE) ${ }^{10}$ en cuanto no podemos olvidar, de un lado, que el Secretario judicial forma parte del órgano jurisdiccional y, de otro, que la potestad jurisdiccional, en un sentido amplio, no incluye sólo la clásica función de juzgar y hacer ejecutar lo juzgado, sino también otras muchas actividades que son necesarias para que esa clásica función pueda ser desempeñada, como puede ser la ordenación del proceso o su documentación; por ese motivo, la propia Constitución atribuye la función de administrar justicia a los jueces y tribunales en el apdo. 1 del art. 117, mientras que en el apdo. 3 de este mismo precepto encomienda la potestad jurisdiccional en sentido amplio a los juzgados y tribunales.

Centrándome en el juicio monitorio, de todas las funciones atribuidas al Secretario judicial, la que tiene mayor relevancia es la competencia para admitir el escrito inicial del procedimiento, dando cuenta al juez cuando entienda que no concurren los requisitos para su admisión. Se trata de una concreción de la atribución general al Secretario judicial de la competencia para admitir la demanda en todo tipo de procesos que se introdujo por esta misma Ley 13/2009 y que generó una gran polémica entre los operadores jurídicos durante su tramitación parlamentaria, en cuanto se consideraba contraria a la Constitución. A este respecto, no se debe olvidar que la admisión de demanda conforma uno de los contenidos esenciales del derecho a la tutela judicial efectiva prevista en el art. 24 $\mathrm{CE},{ }^{11}$ tal como lo ha configurado el Tribunal Constitucional en reiterada

\footnotetext{
9 Vid. a este respecto, la Declaración de Profesionales Jurídicos hacia una administración de justicia del siglo XXI, garantista, racional y eficiente hacia el ciudadano, http://www.coseju.com.

${ }_{10}$ Art. 117 CE “1. La justicia emana del pueblo y se administra en nombre del Rey por Jueces y Magistrados integrantes del poder judicial, independientes, inamovibles, responsables y sometidos únicamente al imperio de la ley.

2. Los Jueces y Magistrados no podrán ser separados, suspendidos, trasladados ni jubilados sino por alguna de las causas y con las garantías previstas en la ley.

3. El ejercicio de la potestad jurisdiccional en todo tipo de procesos, juzgando y haciendo ejecutar lo juzgado, corresponde exclusivamente a los Juzgados y Tribunales determinados por las leyes, según las normas de competencia y procedimiento que las mismas establezcan.

4. Los Juzgados y Tribunales no ejercerán más funciones que las señaladas en el apartado anterior y las que expresamente les sean atribuidas por ley en garantía de cualquier derecho.

5. El principio de unidad jurisdiccional es la base de la organización y funcionamiento de los Tribunales. La ley regulará el ejercicio de la jurisdicción militar en el ámbito estrictamente castrense y en los supuestos de estado de sitio, de acuerdo con los principios de la Constitución.

6. Se prohíben los Tribunales de excepción".

11 Art. 24 CE: "1. Todas las personas tienen derecho a obtener tutela efectiva de los jueces y tribunales en el ejercicio de sus derechos e intereses legítimos, sin que, en ningún caso, pueda producirse indefensión.

2. Asimismo, todos tienen derecho al Juez ordinario predeterminado por la ley, a la defensa y a la asistencia de letrado, a ser informados de la acusación formulada contra ellos, a un proceso público sin dilaciones indebidas y con todas las garantías, a utilizar los medios de prueba pertinentes para su defensa, a no declarar contra sí mismos, a no confesarse culpables y a la presunción de
} 
González - El juicio monitorio en España tras las últimas reformas procesales

jurisprudencia. En efecto, el acceso a los tribunales es el primer contenido de este derecho, de ahí que la atribución de la admisión de demanda a un órgano no jurisdiccional aparecía contraria a la Constitución. ${ }^{12}$

Pues bien, para evitar la duda constitucional, el art. 404.1 LEC atribuye al Secretario judicial la admisión de la demanda que cumpla los requisitos legales; en cambio, cuando el Secretario judicial tenga alguna duda sobre su admisión, tendrá que dar cuenta al juez para que éste decida a través de auto sobre su admisión o rechazo.

En el sistema procesal civil, como una clara manifestación del derecho de acceso a los tribunales, la demanda debe ser admitida con carácter general y sólo se declarará inadmisible en los casos y por las causas previstas expresamente en la ley (art. 403 LEC). Así, en el régimen de admisión de la demanda se parte de que la actividad de admisión es una actuación procesal casi reglada en la que el Secretario judicial debe realizar una comprobación del cumplimiento de la jurisdicción y competencia objetiva y territorial (cuando venga determinada por un fuero imperativo) y de los requisitos formales de la demanda. Si el examen es positivo, el Secretario judicial dictará decreto admitiendo la demanda y dando traslado al demandado para que conteste; por el contrario, cuando dude sobre la concurrencia de algún requisito, dará cuenta al Juez para que decida sobre la admisión. De esta forma queda garantizado plenamente el derecho de acceso a los tribunales.

Este mismo esquema plenamente constitucional se observa en relación al juicio monitorio, pues el Secretario judicial, con carácter general, deberá admitir la petición inicial salvo que tenga dudas sobre el cumplimiento de los requisitos establecidos expresamente en la ley, esto es, la competencia, tanto objetiva como territorial, (art. 813 LEC), los requisitos relativos al contenido de la petición inicial (art. 814 LEC) y la aportación de alguno de los documentos contenidos en el art. 812 LEC. Comprobada la concurrencia de los requisitos legales, el Secretario judicial requerirá de pago al deudor por un plazo de 20 días. Si, en el caso contrario, entendiera que no se cumple alguno de los presupuestos legales, "dará cuenta el Juez para que resuelva lo que corresponda sobre la admisión a trámite de la petición inicial” (art. 815.1 in fine LEC).

inocencia. La ley regulará los casos en que, por razón de parentesco o de secreto profesional, no se estará obligado a declarar sobre hechos presuntamente delictivos".

12 Además de su vertiente constitucional, la admisión de demanda produce, como ya sabemos, toda una serie de efectos tanto procesales como materiales. A modo de recordatorio, los efectos procesales de la demanda son: la perpetuatio jurisdictionis (art. 411 LEC), la perpetuatio legitimationis (art. 413 LEC), la prohibición de la mutatio libellis (art. 412 LEC) y la litispendencia en sentido estricto (arts. 416 y 421 LEC); en cuando a los materiales, se concretan en la interrupción de los plazos de prescripción (art. 1973 CC), la constitución del deudor en mora (art. 1100 CC), la obligación del deudor de pagar intereses (art. 1109 CC), y la condición de litigiosos de los bienes (art. 1535 CC). 
Ahora bien, en aquellos supuestos en que el demandante solicite en su petición inicial una medida cautelar (normalmente, un embargo preventivo), ${ }^{13}$ no tendrá el Secretario judicial competencia para decidir sobre su admisibilidad; no se trata ya aquí de una actividad reglada de comprobación de la regularidad formal de un documento así como de la concurrencia de unos presupuestos procesales, sino que deberá valorarse aquí si la medida cautelar es necesaria para garantizar la efectividad de la tutela judicial que se pretende con el juicio monitorio. En consecuencia, será el juez, a través de auto, quien resuelva sobre la petición cautelar (arts. 721 y 726 LEC).

Como una manifestación más de que la admisión de la petición inicial por parte del Secretario judicial es una actividad reglada y que cualquier duda sobre la misma debe ser comunicada al juez para que él decida, el nuevo apdo. 3 del art. 815 LEC, introducido por la Ley 4/2011, de 24 de marzo, señala que "Si de la documentación aportada con la petición se desprende que la cantidad reclamada no es correcta, el Secretario judicial dará traslado al Juez, quien, en su caso, mediante auto podrá plantear al peticionario aceptar o rechazar una propuesta de requerimiento de pago por el importe inferior al inicialmente solicitado que especifique". Esta nueva previsión será comentada más en profundidad en el apartado correspondiente a la reforma introducida por la Ley 4/2011.

Además de esta función, el Secretario judicial se encargará de la tramitación del todo el juicio monitorio hasta su terminación como indican los arts. 812 a 818 LEC, en coherencia con el objetivo perseguido por la Ley 13/2009, de descargar al juez de todas las funciones que no sean de carácter estrictamente jurisdiccional. Así, le corresponde el examen de la admisibilidad de la petición inicial, el requerimiento de pago al deudor y la conclusión de las actuaciones ante la oposición del deudor, transformando el monitorio en juicio verbal o en ordinario, dependiendo de la cuantía. ${ }^{14}$

\footnotetext{
13 Frente a lo que ocurre con el juicio monitorio de reclamación de deudas comunes de la Comunidad de Propietarios en el que, de acuerdo con el art. 21.5 LPH el acreedor podrá solicitar embargo preventivo de los bienes del deudor si el mismo formula oposición, o el juicio cambiario donde el art. 821 prevé el embargo preventivo de los bienes del deudor por la cantidad que figura en el título cambiario. Estas dos previsiones llevaron a un sector de la jurisprudencia a cuestionarse la viabilidad de las medidas cautelares en el juicio monitorio.

Sin embargo, pronto la mayoría de las Audiencias Provinciales empezaron a pronunciarse a favor de la adopción de medidas cautelares en este juicio a la vista del carácter declarativo del mismo y la finalidad perseguida por las medidas cautelares. En este sentido, AAP de Zaragoza, de 8 de noviembre de 2002 (JUR 2003/30694).

${ }^{14}$ Esto ha llevado a algún autor a criticar la nueva configuración del juicio monitorio al considerar que se ha desjudicializado completamente. Vid. al respecto, BANACLOCHE PALAO, Julio, "El proyecto de Nueva Oficina Judicial: ¿hacia un nuevo proceso administrativizado?”, La Ley, núm. 7251, 2009, http://www.laley.es; HERRERO PEREZAGUA, Juan F., "La reforma del proceso monitorio por la Ley 13/2009”, BIB 2010/1685, http://www.weslaw.es.
} 
González - El juicio monitorio en España tras las últimas reformas procesales

\section{b) Unificación de las formas de terminación del juicio monitorio}

Como señala la propia Exposición de Motivos de la Ley 13/2009, otro de los objetivos perseguidos en relación al juicio monitorio es "dar uniformidad a las formas de terminación de este procedimiento, dado que el proceso monitorio constituye un proceso declarativo especial que se transforma en un procedimiento distinto, en la medida en que su naturaleza jurídica cambia, cuando el deudor requerido no paga, ya sea formulando o no oposición”.

Así, frente a lo que previsto en la redacción originaria de la LEC, se ha establecido la terminación del procedimiento por decreto del Secretario judicial cuando se acuerde el archivo por pago (art. 817 LEC); la inactividad del deudor también dará lugar a la finalización del juicio por decreto y su notificación al acreedor para que inste el despacho de ejecución (art. 816 LEC); ante la oposición del deudor, cuando la cuantía de la reclamación es inferior a 6.000 euros, el Secretario dictará auto dando por terminado el monitorio y acordando seguir la tramitación de acuerdo con las normas del juicio verbal; y, cuando la cuantía de la deuda supera los 6.000, se dará traslado del escrito de oposición al acreedor para que presente demanda de juicio ordinario dentro del plazo de un mes desde el traslado del citado escrito (art. 818 LEC).

Esta uniformidad en relación a la forma de terminación del juicio monitorio, aclara una cuestión de gran importancia que estaba dando lugar a una gran polémica a nivel jurisprudencial; me refiero a la posible vinculación entre el escrito de oposición y la fase de alegaciones del posterior proceso ordinario por la cuantía, ${ }^{15}$ puesto que tras la reforma operada por la Ley 13/2009 queda claro que el juicio monitorio y el posterior juicio, ya sea verbal u ordinario, son dos procedimientos distintos, en cuanto el Secretario judicial pone fin al proceso monitorio a través del correspondiente decreto. De acuerdo con esta consideración, no debería existir razón alguna para limitar las facultades de alegación del deudor en el juicio ordinario que corresponda, que, no olvidemos, es de carácter plenario. ${ }^{16}$

\footnotetext{
15 Para un sector de la jurisprudencia, no será posible que el deudor en el posterior proceso declarativo alegue motivos de oposición que no fueron incluidos previamente en el citado escrito; entre otras, SSAP de Valencia, de 22 de noviembre (PROV 2008/110154); de Badajoz, de 12 de julio de 2007 (JUR 2007/317781); de Asturias, de 27 de agosto de 2007 (JUR 2007/51880); de Murcia, de 22 de abril de 2010 (JUR 2010/203035).

Por el contrario, para otro, el contenido del escrito de oposición no vincula al deudor en el posterior proceso declarativo, de tal forma que podrá incluir los motivos de oposición que en este momento considere oportunos; entre otros, SSAP de Toledo, de 20 de febrero de 2006 (AC 2006/189); de Pontevedra, de 30 abril de 2010 (JUR 2008/303733); de Cantabria, de 23 de febrero de 2010 (JUR 2010/358639).

16 Ahora bien, siendo cierto lo anteriormente, no podemos olvidar que del tenor de la propia regulación del juicio monitorio se desprende que se ha querido dar un tratamiento distinto a las pretensiones dependiendo de su cuantía, como sabemos, lo que repercute en gran medida en las facultades de alegación de las partes en el posterior proceso ordinario.
} 
Por otra parte, se introducen dos modificaciones que tratan de resolver dudas doctrinales sobre dos cuestiones concretas; en la primera de ellas, se modifica el art. 817 LEC, regulador del pago del deudor. En su redacción original, este precepto señalaba que "si el deudor atendiere el requerimiento de pago, tan pronto como lo acredite, se le hará entrega de justificante de pago y se archivarán las actuaciones", mientras que tras la reforma operada por la Ley 13/2009, se elimina la entrega del justificante de pago por parte del Secretario judicial.

Con esta reforma, se trata de adecuar la situación a la realidad existente en nuestros juzgados. A saber, ante el requerimiento de pago, el deudor si quería cumplir la obligación contraída con el acreedor, habitualmente acudía a dos formas para realizar el pago de la deuda reclamada. La primera de ellas era la consignación de la cantidad debida en el juzgado en cuyo caso, se actuaba de conformidad con lo establecido en el art. 817 LEC, esto es, archivando las actuaciones a través de auto en el que se hacía constar el justificante de pago del deudor. La segunda era el pago directo de la cantidad al acreedor, esto es, el deudor procedía a realizar un cumplimiento extrajudicial de la obligación y acreditaba ese cumplimiento ante el órgano jurisdiccional. En estos casos, y salvo cuando la acreditación era indiscutible (por ejemplo, se presentaba por el deudor el ingreso en una cuenta del acreedor junto con un recibo firmado por el mismo), precisamente como una garantía más para el acreedor, se comunicaba esa acreditación al acreedor dándole un plazo para que alegase lo que estimase oportuno sobre el cumplimiento; seguidamente, de ser el caso, se dictaba auto de archivo en el que se hacía constar el justificante de pago del deudor.

En efecto, cuando la cuantía de la deuda es inferior a 6.000 euros, presentada oposición sucintamente motivada por el deudor, el Secretario judicial convocará a las partes a la audiencia del juicio verbal, una vez dictado decreto que ponga fin al juicio monitorio. Esto es, se seguirán los trámites del juicio verbal, de tal forma que el acreedor sólo podrá, en la vista, ratificar o complementar el contenido de su demanda, no pudiendo incluir fundamentos nuevos de los aportados previamente, por imperativo de lo establecido en el art. 443 LEC; en otras palabras, podrá complementar o desarrollar lo alegado en su momento en su petición inicial, pero no podrá incluir nuevos motivos a los ya expuestos. En cuanto al demandado, al igual que el demandante, también verá limitadas sus facultades de alegación a las previamente plasmadas en su escrito de oposición en cuanto la inclusión de nuevos motivos podría suponer una clara limitación del derecho de defensa del acreedor que no podrá contrarrestar estos motivos en otro momento procesal.

Frente a lo anterior, cuando la cuantía de la reclamación es superior a 6.000 euros, presentada aposición se emplazará al acreedor a que presente demanda propia del juicio ordinario en el plazo de 30 días, no habiendo en este caso ningún tipo de limitación en sus alegaciones frente a las incluidas previamente en la petición inicial del monitorio; en coherencia con esto, tampoco el deudor se verá vinculado por las causas de oposición alegadas en su petición inicial si no que podrá contestar a las alegaciones incluidas en la demanda del acreedor sin que pueda verse limitado su derecho de defensa.

Vid. al respecto, GONZÁLEZ PILLADO, Esther, "Comentario a la SAP, de Ourense (Sección $1^{\text {a }}$, del 20 de julio del 2010. La oposición del deudor en el juicio monitorio y su conexión con el proceso ordinario posterior", en Revista Xurídica Galega, núm. 67, 2010, pp. 233 a 238. 
González - El juicio monitorio en España tras las últimas reformas procesales

Con la segunda modificación operada por la Ley 13/2009, se deja claro que el despacho de la ejecución, posterior a la constatación de la falta de actuación del deudor dentro del plazo de 20 días desde el requerimiento de pago, no es automático, sino que requiere de previa petición del acreedor (art. 816.1 LEC). Con esta previsión se pone fin a la controversia doctrinal y jurisprudencial sobre si la falta de pago u oposición del deudor suponía el inicio automático de la ejecución, optándose porque el deudor inste el despacho de la misma.

En efecto, antes de la Reforma operada por la Ley 13/2009, el art. 816.1 LEC, ante la incomparecencia del deudor, establecía que "éste (el juez) dictará auto en el que despachará ejecución por la cantidad adeudada"; pronto empezaron a surgir dudas sobre si el despacho de ejecución debía hacerse de oficio o era necesario interponer por parte del acreedor demanda ejecutiva. Ante esta disyuntiva, la mayoría de la doctrina y la jurisprudencia optó por la apertura del proceso de ejecución de oficio por parte del juez, ${ }^{17}$ pese a la existencia de argumentos que podían llevar a la defensa de la postura contraria. ${ }^{18}$ A saber, el despacho de ejecución de oficio podía llevar al incumplimiento del art. 539.1 $\mathrm{LEC}^{19}$ que, frente a la norma general vigente en el juicio monitorio, exigía la intervención de abogado y procurador para el despacho de ejecución cuando la cuantía de la deuda era superior a 2.000 euros; otra dificultad derivada del despacho de ejecución de oficio era la falta de designación de bienes de deudor susceptibles de embargo por parte del acreedor o, en su caso, las medidas de localización o investigación que solicita al órgano jurisdiccional, de acuerdo con el art. 549.1 LEC. $^{20}$

\footnotetext{
${ }^{17}$ Entre otros, ARMENTA DEU, Teresa, Lecciones de Derecho Procesal Civil, 2004, p. 582; CORTÉS DOMÍNGUEZ, Valentín, Derecho Procesal Civil. Parte Especial (con Moreno Catena), 2008, pp. 172 y 173; GÓMEZ COLOMER, Juan Luis, Derecho Jurisdiccional II. Proceso Civil (con Montero Aroca, Montón Redondo y Barona Villar), 2004, pp. 784 y 785.

Entre la jurisprudencia, entre otros, AAP de Santa Cruz de Tenerife, de 14 de octubre de 2009 (JUR 2010/79417); de Santa Cruz de Tenerife, de 3 de marzo de 2009 (AC 2009/1275); de Madrid, de 11 de enero de 2006 (AC 2006/174); de Cádiz, de 27 de julio de 2005 (AC 2005/1648); de Madrid, de 7 de septiembre de 2004 (JUR 2004/274722);

${ }^{18}$ En este sentido, AAP de Valencia, de 3 de marzo de 2005 (PROV 2005/131564).

${ }^{19}$ Artículo 539. Representación y defensa. Costas y gasto de la ejecución.

1. El ejecutante y el ejecutado deberán estar dirigidos por letrado y representados por procurador, salvo que se trate de la ejecución de resoluciones dictadas en procesos en que no sea preceptiva la intervención de dichos profesionales.

Para la ejecución derivada de procesos monitorios en que no haya habido oposición, se requerirá la intervención de abogado y procurador siempre que la cantidad por la que se despache ejecución sea superior a 2.000 euros.

20 Artículo 549. Demanda ejecutiva. Contenido.

1. Sólo se despachará ejecución a petición de parte, en forma de demanda, en la que se expresarán: $1^{\circ} \mathrm{El}$ título en que se funda el ejecutante.

$2^{\circ}$ La tutela ejecutiva que se pretende, en relación con el título ejecutivo que se aduce, precisando, en su caso, la cantidad que se reclame conforme a lo dispuesto en el artículo 575 de esta Ley.
} 
Pues bien, esta polémica queda ahora solventada con la nueva redacción del art. 816.1 LEC, siendo en todo caso preceptivo que el acreedor solicite el despacho de ejecución, bastando con ello una mera solicitud (que en todo caso podrá ajustarse a lo previsto en el art. 549.1 LEC, regulador de la demanda ejecutiva).

\section{c) Notificación del requerimiento de pago al deudor}

Otra de las grandes dudas existentes en relación al juicio monitorio, era la referida a la forma de notificar al deudor el requerimiento de pago y, más concretamente, si era posible realizarlo a través de edictos. La discusión doctrinal tenía su base en el art. 815.1 LEC que, al referirse a esa notificación, se remitía al art. 161 LEC, donde se regula con carácter general la forma de practicar las comunicaciones, y que a su vez se remite al art. 156 LEC. Si se acude a este último precepto, en el supuesto en que no es posible realizar la comunicación, ante el desconocimiento del domicilio del deudor, y realizadas infructuosamente todas las averiguaciones previstas (art. 156.1 LEC), permite realizarla a través de edictos.

La remisión indirecta al art. 156 LEC, la falta de previsión en contra de la utilización de la notificación edictal en el juicio monitorio ordinario y su admisión expresa por parte del art. 815.2 LEC en el caso de reclamaciones monitorias de deudas derivadas de gastos comunes contraídos con la Comunidad de propietarios, ${ }^{21}$ podía llevar a entender que la notificación del requerimiento de pago al deudor podía ser realizada a través de edictos.

\footnotetext{
$3^{\circ}$ Los bienes del ejecutado susceptibles de embargo de los que tuviere conocimiento y, en su caso, si los considera suficientes para el fin de la ejecución.

$4^{\circ}$ En su caso, las medidas de localización e investigación que interese al amparo del artículo 590 de esta Ley.

$5^{\circ}$ La persona o personas, con expresión de sus circunstancias identificativas, frente a las que se pretenda el despacho de la ejecución, por aparecer en el título como deudores o por estar sujetos a la ejecución según lo dispuesto en los artículos 538 a 544 de esta Ley.

${ }^{21}$ En efecto, el art. 815.2 LEC señala que "En las reclamaciones de deuda a que se refiere el número $2^{\circ}$ del apartado 2 del artículo 812 (deudas contraídas con la Comunidad de Propietarios), la notificación deberá efectuarse en el domicilio previamente designado por el deudor para las notificaciones y citaciones de toda índole relacionadas con los asuntos de la comunidad de propietarios. Si no se hubiere designado tal domicilio, se intentará la comunicación en el piso o local, y si tampoco pudiere hacerse efectiva de este modo, se le notificará conforme a lo dispuesto en el artículo 164 de la presente Ley.

Como acertadamente señala HERRERO PEREZAGUA, Juan F. ("La reforma del proceso monitorio por la Ley 13/2009" (nota 15), p. 7) esta excepción se justifica por dos razones: de un lado, por la carga de designación de un domicilio que tiene cada propietario para que se practiquen las citaciones y notificaciones de la Comunidad de propietarios; de otro, que con carácter previo a la incoación del juicio monitorio, el deudor ha tenido dos ocasiones para conocer la existencia y la cuantía de la deuda: en el momento de la celebración de la Junta de propietarios en que se aprobó la liquidación de la deuda, y en el momento en que se le notificó dicho acuerdo.
} 
González - El juicio monitorio en España tras las últimas reformas procesales

Sin embargo, la mayoría de la doctrina se mostró en contra de la utilización de la comunicación edictal en el juicio monitorio por una razón fundamental centrada en el papel esencial que tiene el requerimiento de pago en este proceso en cuanto de su efectivo conocimiento por el deudor depende la posibilidad de que el mismo pueda actuar ante un despacho de ejecución que se va a dirigir contra él. Es decir, presumir que el deudor reconoce el crédito por su incomparecencia, exige tener la certeza de que esa inactividad es voluntaria y eso sólo se logra si la notificación del requerimiento de pago se ha realizado de forma personal; por el contrario, esa certeza no se consigue con la comunicación edictal que parte de la ficción de que el deudor ha conocido el requerimiento por su exposición en el tablón de anuncios de la Oficina judicial o, en su caso, su publicación en el Boletín Oficial o diario de difusión nacional o provincial (art. 164 LEC). ${ }^{22}$

En cuanto a la jurisprudencia, también se ha manifestado en contra de la utilización de la comunicación edictal en el juicio monitorio al considerar que la misma "es absolutamente incompatible con la naturaleza del mismo". ${ }^{23}$ Una buena muestra de los argumentos utilizados por la jurisprudencia se encuentra en el AAP de Jaén, de 20 de octubre de 2009 cuando señala que "este procedimiento (el monitorio) supone una vía especial para acceder al proceso de ejecución, basada inicialmente en documentos de una notable debilidad probatoria pero que no obstante ellos pueden permitir acceder a un proceso de ejecución en atención a la ineludible respuesta que el legislador exige que el aparente deudor dé al requerimiento de pago, interpretándose el requerimiento como aquietamiento. En este sentido debe recordarse que la llave que permite acceder a este procedimiento monitorio y, en su caso, al proceso de ejecución es no tanto el soporte acreditativo del crédito del demandante, sino la postura que el demandado adopta. Postura que es exigida e interpretada rígidamente por el legislador. De hecho, con independencia de cuál sea la conducta que el deudor requerido de pago adopte frente a la intimidación judicial, si el mismo cumple escrupulosamente todas las previsiones legales y, en particular, las relativas a la comunicación personal al deudor del requerimiento de pago, éste se habrá realizado con pleno respeto a las garantías constitucionales... Por ello, hay que entender que el reenvío al art. 156 LEC vía art. 161 LEC, único precepto a que se refiere expresamente el art. 815.1 LEC, lo sería a los efectos de la realización de gestiones para la averiguación del domicilio del presunto deudor, pero sin extender la remisión más allá (a la comunicación edictal)". Continúa señalando la AP de Jaén que "obviar el contradictorio en esas condiciones exige una ineludible certeza y un mínimo de garantías procesales en el acto de la comunicación judicial que tanta trascendencia puede llegar a tener, pues no sólo abre la vía a la ejecución sino que impide que

\footnotetext{
${ }^{22}$ Entre otros, ARMENTA DEU, Teresa, Lecciones de Derecho Procesal (nota 18), p. 581; GÓMEZ COLOMER, Juan Luis, "Comentarios prácticos a los arts. 812 a 818 del Capítulo I del Título IV de la Ley de Enjuiciamiento Civil: del proceso monitorio", en Ejecución judicial de títulos extrajudiciales. Juicio cambiario y monitorio, Estudios de Derecho Judicial, núm. 69, 2005, p. 421; MAGRO SERVET, Vicente, El proceso monitorio, 2006, p. 116.

23 AAP de Madrid, de 9 de marzo de 2004 (JUR 2004/249328).
} 
con posterioridad el demandado haga cuestión de lo que se le exigió en el monitorio: no podrá pretender ulteriormente en un ordinario "la devolución (de la cantidad) de la que con la ejecución se obtuviere". Garantías de que llegue a conocimiento del deudor que no quedan, desde luego, atendidas por una comunicación tan ficticia como la edictal". ${ }^{24}$

La discusión doctrinal y jurisprudencial se supera ahora con la nueva redacción del art. 815.1 LEC cuando dispone expresamente que "sólo se admitirá el requerimiento al demandado por medio de edictos en el supuesto regulado en el siguiente apartado de este artículo" (deudas derivadas de gastos comunes de la Comunidad de propietarios). ${ }^{25}$

\section{d) Ampliación de la cuantía del juicio monitorio}

La Ley 13/2009 eleva la cuantía del juicio monitorio de $30.000^{26}$ a 250.000 euros en el art. 812 LEC. Se persigue, como señala la Exposición de Motivos de la Ley, "dar más cobertura a un proceso que se ha mostrado rápido y eficaz para el cobro de deudas dinerarias vencidas, exigibles y documentadas. La sencillez del procedimiento y su utilidad como forma de protección del crédito ha provocado una utilización masiva del mismo que, por sí sola, justifica ampliar su ámbito de aplicación; es el proceso más utilizado para la reclamación de cantidades. Por otro lado, se ha mostrado como una vía para evitar juicios declarativos contradictorios, con la consiguiente descarga de trabajo para los órganos jurisdiccionales; más del cincuenta por ciento de los procesos monitorios evita el consiguiente declarativo, al finalizar el procedimiento bien mediante el pago voluntario por el deudor, bien por ejecución del título base de la petición inicial”.

\footnotetext{
24 AAP de Jaén, de 20 de octubre de 2009 (JUR 2010/10028).

En esta misma línea, entre otros, AAP de Navarra, de 25 de enero de 2010 (AC2010/5); de Burgos, de 18 de marzo de 2009 (JUR 2009/234671); de Barcelona, de 15 de enero de 2009 (AC 2009/565).

No obstante, también existe jurisprudencia en sentido contrario, así, entre otros, el AAP de Las Palmas, de 9 de julio de 2007 (AC2007/1921) señala que "si el legislador hubiera querido excluir al juicio monitorio de la práctica de notificaciones y requerimientos por edictos, hubiera sido fácil establecerlo así. La ausencia de esta exclusión debe proscribir toda interpretación que ciegue el ejercicio de acciones judiciales establecidas en la Ley, abonando además el terreno para ocultaciones de domicilio y otro tipo de fraudes procesales."

${ }^{25}$ Pese a que esta reforma está en la línea de la doctrina y jurisprudencia mayoritaria, existe alguna voz crítica con esta modificación al entender que la prohibición de la utilización de edictos dificulta el funcionamiento y la efectividad del juicio monitorio. Vid. en este sentido, NAVARRO RODRÍGUEZ, Sonia, "Reformas procesales contra la morosidad", Diario La Ley, núm. 7568, 2011, http://www.laley.es.

${ }^{26}$ La LEC en su redacción original del 7 de enero de 2000, expresaba las cuantías en pesetas (en el caso del juicio monitorio eran 5.000.000 de pesetas) y el Real Decreto 1417/2001, de 17 de diciembre, procedió a su conversión en euros en virtud de la habilitación contenida en el apartado segundo de la Disposición Adicional $2^{a}$ LEC, que exigía la eliminación de las fracciones.
} 
González - El juicio monitorio en España tras las últimas reformas procesales

De esta forma, el legislador, aunque aumenta la cuantía, sigue siendo "prudente" y no suprime el límite cuantitativo para las pretensiones que se hacen valer por este procedimiento, pese a ser ésta la línea seguida tanto por los países del entorno europeo ${ }^{27}$, como en el ámbito comunitario, como así se refleja en el Reglamento (CE) no 1896/2006 del Parlamento Europeo y del Consejo, de 12 de diciembre de 2006 , por el que se establece un proceso monitorio europeo.

No parece fácil llegar a comprender las razones que llevaron al legislador a establecer este nuevo límite cuantitativo a un juicio que, durante los años de vigencia de la Ley procesal civil ha demostrado su utilidad para los operadores jurídicos y cuando los ordenamientos de nuestro entorno más cercano, como ya se ha apuntado, tampoco tienen esas limitaciones de cuantía.

El mantenimiento de un límite máximo hace que sigan produciéndose los problemas derivados del fraccionamiento por parte de los acreedores de las deudas que superen el límite fijado; aunque bien es cierto que los problemas son menores como consecuencia de la elevación de la cantidad máxima reclamable de 30.000 a 250.000 euros.

Habrá que esperar hasta la reforma de la LEC operada por la Ley 37/2011, de 10 de octubre, de medidas de agilización procesal, para la resolución de estos problemas ante la supresión del límite cuantitativo del juicio monitorio. ${ }^{28}$

\section{Reforma operada por la Ley 19/2009, de 23 de noviembre}

La Exposición de Motivos de la Ley 19/2009, de 23 de noviembre, de medidas de fomento y agilización procesal del alquiler y de la eficiencia energética de los edificios, parte de la constatación de que el alquiler no ha sido la opción mayoritariamente escogida por los ciudadanos españoles en los últimos años para acceder a la vivienda, pese a las grandes ventajas económicas, sociales y laborales que ofrece el alquiler (v. gr. facilita la elección de vivienda de los ciudadanos, adecuándola a las diferentes necesidades del ciclo vital, propicia el aumento de la movilidad geográfica de los trabajadores, permite disminuir el endeudamiento de los hogares y ofrece mayor flexibilidad ante cambios en los ingresos de la unidad familiar).

Ante esta situación, y pese al incremento en los últimos años de nuevos hogares que acceden a una vivienda en régimen de alquiler, siguen siendo necesarias medidas de estímulo, tanto las dirigidas a ayudar a las familias de menor

\footnotetext{
27 Países como Italia, Alemania o Francia no establecen límites en la cuantía del juicio monitorio siempre que la misma sea determinada.

${ }^{28}$ Vid. apdo. 5 donde se analizará la reforma operada por la Ley 37/2011, así como los problemas que se resuelven con su aprobación.
} 
capacidad económica y las orientadas a facilitar la emancipación de los jóvenes, como para fortalecer la seguridad jurídica de las partes. ${ }^{29}$

Así, se modifican diversos preceptos de la Ley de Enjuiciamiento Civil con el propósito de mejorar y agilizar los procesos de desahucio, salvaguardando en todo caso los derechos y garantías que protegen al inquilino de buena fe. Por ejemplo, se amplía también el ámbito del juicio verbal para que puedan sustanciarse por este procedimiento las reclamaciones de rentas derivadas del arrendamiento cuando no se acumulan al desahucio, lo que permite salvar, en su caso, la relación arrendaticia, algo que hasta ahora se dificultaba porque el propietario acreedor de rentas o cantidades debidas se veía obligado a acumular su reclamación a la del desahucio si quería acudir al juicio verbal, más sencillo y rápido que el juicio ordinario. Además, en varios supuestos se reducen plazos y se eliminan trámites no sustanciales que hasta ahora dilataban en exceso la conclusión del proceso.

A los efectos que interesan aquí, se establece que cuando las reclamaciones de rentas o de cantidades debidas accedan al proceso monitorio y se formule oposición por el arrendatario, la resolución definitiva seguirá los trámites del juicio verbal, cualquiera que sea su cuantía. Por este motivo, se añade un nuevo apartado 3 al artículo 818, que queda redactado del siguiente modo: "En todo caso, cuando se reclamen rentas o cantidades debidas por el arrendatario de finca urbana y éste formulare oposición, el asunto se resolverá definitivamente por los trámites del juicio verbal, cualquiera que sea su cuantía".

Esta previsión guarda coherencia con la nueva redacción de los arts. 249.1.6 y 250.1.1 ${ }^{\circ}$ LEC, modificados también por la misma Ley 19/2009, que establecen que el mecanismo procesal para las reclamaciones de rentas vencidas en arrendamientos urbanos es el juicio verbal. Esto es, se acudirá al juicio verbal en los casos de demandas que "versen sobre reclamación de cantidades por impago de rentas y cantidades debidas y las que, igualmente, con fundamento en el impago de la renta o cantidades debidas por el arrendatario, o en la expiración del plazo fijado contractual o legalmente, pretendan que el dueño, usufructuario o cualquier otra persona con derecho a poseer la finca rústica o urbana dada en arrendamiento, ordinario o financiero o en aparcería, recuperen la posesión de la finca".

En lo que respecta al juicio monitorio, la reclamación de cantidades derivadas del incumplimiento del pago de la renta por arrendamiento de viviendas a través de este procedimiento, no se planteó inicialmente con la entrada en vigor de la LEC; sin embargo, con el transcurso del tiempo empezaron a presentarse monitorios basados en recibos de rentas impagadas, aunque lo habitual es acudir al

\footnotetext{
${ }^{29}$ El otro objetivo de la Ley se centra en continuar las reformas que permiten incrementar la eficiencia energética de los edificios en España, de ahí que se modifique la Ley de Propiedad Horizontal para hacer mejoras en ese sentido.
} 
González - El juicio monitorio en España tras las últimas reformas procesales

procedimiento de resolución del contrato por la falta de pago y ejercicio de la acción acumulada de reclamación de cantidad. ${ }^{30}$

Pronto surgieron dudas sobre la admisibilidad de la reclamación como deuda monitoria de las rentas debidas por arrendamiento de viviendas por dos razones concretas, de un lado, por la existencia de un procedimiento especialmente establecido en nuestra ley procesal civil; y de otro, por la exigencia documental del art. 812 LEC. Sin embargo, la posición mayoritaria se inclinó a favor de la utilización del juicio monitorio, rechazando los dos argumentos anteriores, en cuando, por una parte, en el proceso civil rige el principio dispositivo de tal forma que, salvo que exista una previsión imperativa al respecto, el demandante podrá elegir entre las distintas modalidades procesales existentes, aquella que mejor se adapte a sus intereses; de otra, porque los documentos utilizados para la reclamación de rentas cumplen con la exigencia contenida en el art. 812.1.2 $2^{\circ}$ LEC para el juicio monitorio, en concreto, los recibos impagados acompañados del contrato de arrendamiento. ${ }^{31}$

Con la introducción del nuevo apdo. 3 del art. 818 LEC queda clara la posibilidad de utilizar el juicio monitorio para la reclamación de rentas debidas al arrendatario de finca urbana, además de darse celeridad a la oposición en estos casos al reconducir la tramitación de la misma siempre al juicio verbal con independencia de la cuantía.

\section{Reforma de la Ley 4/2011, de 24 de marzo}

Ley 4/2011, de 24 de marzo, de modificación de la Ley 1/2000, de 7 de enero, de Enjuiciamiento Civil, para facilitar la aplicación en España de los procesos europeos monitorio y de escasa cuantía, tiene como objetivo esencial la incorporación en el ordenamiento jurídico español de las disposiciones necesarias para permitir una adecuada utilización por los operadores jurídicos de dos instrumentos comunitarios de protección del crédito, el Reglamento (CE) 1896/2006 del Parlamento Europeo y del Consejo, de 12 de diciembre de 2006, por el que se establece un proceso monitorio europeo, y el Reglamento (CE) 861/2007 del Parlamento Europeo y del Consejo, de 11 de julio de 2007, por el que se establece un proceso europeo de escasa cuantía. ${ }^{32}$

\footnotetext{
${ }^{30}$ Acumulación permitida por el art. 438.3.3 $3^{\circ}$ LEC.

31 A favor de la utilización del juicio monitorio para la reclamación de rentas, entre otros, AAP de Zaragoza, de 5 de julio de 2002 (JUR 2002/227206).

En contra, AJ1'I de Tenerife, de 21 de mayo de 2001 (JUR 2001/173708).

32 De una forma muy sintética, se trata de dos procedimientos europeos que persiguen la mejora del tratamiento de las reclamaciones transfronterizas en el ámbito de la Unión Europea. En concreto, el Reglamento sobre el proceso monitorio europeo crea un proceso civil especial para litigios transfronterizos de créditos pecuniarios no impugnados, que culmina, en su caso, en un requerimiento europeo de pago que nace ya con el carácter de título de ejecución, y que podrá ejecutarse en cualquier Estado miembro de la Unión Europea sin trámites intermedios ni
} 
En ambos casos, se trata de disposiciones que son de aplicación directa en España, sin necesidad de ninguna norma de transposición, lo que no exime al legislador español de aprobar las normas precisas para integrar esos dos nuevos procesos con las leyes procesales vigentes y, en especial, con la Ley de Enjuiciamiento Civil, y colmar así las lagunas de tales Reglamentos y facilitar su aplicación. Como señala la propia Exposición de Motivos de la Ley 4/2011, "el objeto de estos preceptos se limita a precisar aquellas disposiciones de las normas de la Unión Europea que lo requieren y, en concreto, los temas de competencia judicial, tipo de resoluciones a adoptar por el Juez o el Secretario judicial y su enlace con el formulario de los Reglamentos europeos que corresponda al trámite de que se trate, los recursos procedentes con arreglo a nuestro Derecho, y normas procesales supletorias en cada caso". ${ }^{33}$

Pero además de las previsiones relativas a los procesos europeos de escasa cuantía y monitorio, se aprovecha esta ley para introducir otro tipo de modificaciones en la Ley de Enjuiciamiento Civil relativas al juicio monitorio, que nuevamente trata de ir resolviendo cuestiones que la realidad práctica iba poniendo de manifiesto en su día a día, como se expone seguidamente.

\section{a) Modificaciones en materia de competencia}

La propia configuración del juicio monitorio hace que gran parte de su éxito dependa de la localización del deudor que hará posible que el requerimiento de pago llegue a su destinatario de forma rápida y efectiva; en íntima conexión con esa localización, es de especial importancia la determinación del órgano competente, tanto desde el punto de vista objetivo como territorial, para la tramitación del juicio monitorio.

\section{i) Competencia objetiva}

El art. 813 LEC ha establecido que la competencia objetiva para conocer del juicio monitorio le corresponde al Juzgado de Primera Instancia, o de lo Mercantil, pese al silencio de la LEC. A este respecto, debe criticarse que ninguna de las reformas procesales operadas desde 2003 ha tenido en cuenta que ese año, con la aprobación de la Ley de Reforma Concursal (LO 8/2003, de 9 de julio), se modificó la LOPJ, creando los Juzgados de lo Mercantil a los que se atribuyó competencia para conocer en primera instancia de los asuntos de carácter civil y

necesidad de homologación. Por su parte, el proceso europeo de escasa cuantía es un proceso declarativo ordinario que abarca cualquier clase de pretensión transfronteriza sea o no pecuniaria, pero cuyo valor no supere los 2.000 euros, que se tramitará de forma escrita y culminará con una sentencia que será certificada como título de ejecución transfronterizo, que circulará libremente por los Estados miembros, pudiendo ser ejecutado en cualquiera de ellos como si fuera un título nacional.

33 Apartado III Ley 4/2011, de 24 de marzo. 
González - El juicio monitorio en España tras las últimas reformas procesales

mercantil que se enumeran en el art. 86 ter. 2 LOPJ. ${ }^{34}$ Así, se desaprovecha la oportunidad de modificar el art. 813 LEC para despejar las posibles dudas sobre la competencia de los Juzgados de lo Mercantil cuando el juicio monitorio versa sobre alguna de las materias atribuidas a estos órganos por el citado art. 86 ter.2 LOPJ.

Es más, antes de la reforma operada por la Ley 13/2009 gran parte de la doctrina y la jurisprudencia entendía que los Juzgados de lo Mercantil podían tramitar un juicio monitorio relativo a alguna de las materias del art. 86 ter.2 LOPJ ${ }^{35}$ sin embargo, el hecho de que la citada Ley deje inalterada la referencia relativa al Juzgado de Primera Instancia en el art. $813,{ }^{36}$ ha hecho surgir la idea de la falta de competencia del Juzgado de lo Mercantil para conocer de un juicio monitorio. $^{37}$

34 Art. 86 ter.2 LOPJ: "Los juzgados de lo mercantil conocerán, asimismo, de cuantas cuestiones sean de la competencia del orden jurisdiccional civil, respecto de:

a) Las demandas en las que se ejerciten acciones relativas a competencia desleal, propiedad industrial, propiedad intelectual y publicidad, así como todas aquellas cuestiones que dentro de este orden jurisdiccional se promuevan al amparo de la normativa reguladora de las sociedades mercantiles y cooperativas.

b) Las pretensiones que se promuevan al amparo de la normativa en materia de transportes, nacional o internacional.

c) Aquellas pretensiones relativas a la aplicación del Derecho Marítimo.

d) Las acciones relativas a condiciones generales de la contratación en los casos previstos en la legislación sobre esta materia.

e) Los recursos contra las resoluciones de la Dirección General de los Registros y del Notariado en materia de recurso contra la calificación del Registrador Mercantil, con arreglo a lo dispuesto en la Ley Hipotecaria para este procedimiento.

f) De los procedimientos de aplicación de los artículos 81 y 82 del Tratado de la Comunidad Europea y de su derecho derivado.

g) Cuantas incidencias o pretensiones se promuevan como consecuencia de la aplicación de la normativa vigente sobre arbitraje en las materias a las que se refiere este apartado".

35 Entre otros, BANACLOCHE PALAO, Julio, Los Juzgados de lo Mercantil: régimen jurídico y problemas procesales que plantea su actual regulación, 2005, pp. 223 y ss.; GONZÁLEZ PILLADO, Esther, "La competencia objetiva en materia no concursal de los Juzgados de lo Mercantil: problemas procesales", en Anuario de la Facultad de Derecho de Ourense, 2006, pp. 276 y 277; MAGRO SERVET, Vicente, El proceso monitorio (nota 23), p. 104; QUÍLEZ ROMERO, José Mª ., El proceso monitorio: estudio doctrinal, jurisprudencial y futura realidad de la e-Justicia, 2011, pp. 189 y ss.

También la jurisprudencia se ha mostrado a favor de atribuir la competencia para conocer del juicio monitorio a los Juzgados de lo Mercantil; así, AAP de Zaragoza, de 13 de octubre de 2009 (PROV 2009/459404); de Barcelona, de 22 de junio de 2007 (PROV 2007/285664); de Sevilla, de 15 de mayo de 2006 (AC 2006/2069); de Madrid, de 25 de mayo de 2006 (PROV 2006/259551); de Madrid, de 7 de marzo de 2006 (JUR 2006/264481).

36 Debe tenerse en cuenta que la Ley 13/2009 modifica el art. 813 LEC en otros aspectos; en concreto, se cambia el término Tribunal por Juzgado, además de cambiar una minúscula por una mayúscula en tribunal.

37 Vid al respecto RODRÍGUEZ ACHÚTEGUI, Edmundo, "De nuevo sobre las dudas del proceso monitorio en el Juzgado Mercantil”, BIB 2010/1502, http://www.westlaw.es. 
Pese a todo, la falta de una adecuada técnica legislativa no nos puede hacer olvidar que los Juzgados de lo Mercantil son órganos especializados para el enjuiciamiento de determinadas materias enumeradas por el legislador en el art. 87 ter.2 LOPJ y ello con independencia del tipo de procedimiento por el que se tramiten las mismas de ahí que, de acuerdo con un claro criterio de competencia objetiva, ante alguna de esas materias, será competente, en todo caso, el citado órgano y no el Juzgado de Primera Instancia.

\section{ii) Competencia territorial}

Para la determinación de la competencia territorial el art. 813.1 LEC prevé varios fueros imperativos ${ }^{38}$ que se pueden clasificar del siguiente modo: en primer lugar, se establecen dos fueros preferentes y alternativos, el domicilio o residencia del deudor; en segundo lugar, un fuero subsidiario, que es el lugar en que el deudor puede ser hallado a efectos de realizar el requerimiento de pago; en tercer y último lugar, y para el supuesto de reclamaciones de deudas comunes de la comunidad de propietarios, se amplía el fuero del domicilio o residencia del deudor al lugar en que se halle la finca, a elección del acreedor.

En consecuencia, la efectiva localización del deudor requiere que el acreedor actúe de forma diligente e incluya en su petición inicial no sólo el domicilio o residencia del deudor, sino cualquier otro lugar en que pueda ser hallado a efectos del requerimiento de pago. Así, podrá designarse el domicilio que conste oficialmente en algún registro público (no sólo en el Padrón municipal) o en las publicaciones de los Colegios profesionales o el lugar en que el deudor desarrolla su actividad profesional o laboral. Ahora bien, a la vista del art. 813.1 LEC, no se debe olvidar que el lugar en que puede ser hallado el deudor a efectos de su requerimiento es un fuero de carácter subsidiario al que sólo se puede acudir ante el desconocimiento del domicilio o residencia del deudor, que es el fuero de aplicación preferente. En otras palabras, no estamos ante fueros electivos del acreedor, debiendo evitarse el posible fraude procesal que se puede producir si el acreedor acabara eligiendo el órgano jurisdiccional según su conveniencia. ${ }^{39}$

Pese a la aparente sencillez de la norma competencial contenida en el art. 813.1 LEC, su aplicación práctica, esto es, la concreta determinación del órgano competente desde el punto de vista territorial, no está exenta de dificultades.

\footnotetext{
${ }^{38}$ El carácter imperativo de estos fueros es una cuestión pacífica en la jurisprudencia; muestra de ello es el ATS de 14 de abril de 2005 (PROV 2006/146901) cuando señala que "la competencia territorial aplicable al proceso monitorio viene determinada por el art. 813 LEC que establece un fuero de naturaleza imperativa... En estos casos (fueros territoriales imperativos) es preciso darle un carácter semejante al dispensado a la competencia objetiva, ya que sus normas específicas carecen del carácter dispositivo que tienen en general las normas sobre competencia territorial (arts. 54 y 59 LEC)".

Igualmente, AAP de Granada, de 29 de septiembre de 2009 (AC 2009/2251).

${ }^{39}$ QUÍLEZ ROMERO, José M${ }^{\mathrm{a}}$., El proceso monitorio: estudio doctrinal, jurisprudencial y futura realidad de la e-Justicia (nota 36), p. 203.
} 
González - El juicio monitorio en España tras las últimas reformas procesales

Precisamente, dos de los problemas prácticos más habituales derivaban de la no localización del deudor o la localización en un partido judicial distinto de aquél donde está ubicado el órgano judicial que admitió la petición monitoria.

A saber, cuando se ha admitido a trámite una petición monitoria y se constata después que el domicilio facilitado por el acreedor no coincide con el actual del deudor, en cuanto no ha sido posible requerirle de pago, se propusieron dos soluciones por la jurisprudencia: o bien, de acuerdo con el art. 411 LEC, que establece la perpetuatio jurisdictionis, entender competente el órgano que admitió la petición monitoria; o bien, considerar incompetente a ese órgano judicial, que podrá inhibirse a favor de aquél que tenga su sede en el partido judicial en que el deudor esté domiciliado. La clave para la aplicación de una u otra solución estaba en el momento en que se había producido el cambio de domicilio, si antes de la presentación y admisión de la petición inicial, en cuyo caso se aplicaba el art. 411 LEC, o con posterioridad a la misma, pudiendo el órgano judicial inhibirse a favor del que estime competente.

A la vista de que los fueros territoriales contenidos en el art. 813.1 LEC son de carácter imperativo, y, por tanto, improrrogables por voluntad de las partes, no parece posible que la mera designación por el acreedor de un domicilio o residencia del deudor en su petición inicial del juicio monitorio impida al órgano jurisdiccional la revisión de oficio de su competencia que será posible en el momento que puede constatar que ese domicilio no se corresponde con la realidad, esto es, en el momento del requerimiento de pago. Si al realizar ese requerimiento se constata que el domicilio del deudor es otro, el Juzgado debería inhibirse, de acuerdo con lo establecido en el art. 58 LEC y remitir las actuaciones al órgano jurisdiccional que estime competente, esto es, el que tenga su sede en el lugar del domicilio efectivo del deudor.

Como consecuencia de lo anterior, el momento en que queda fijada la competencia es una vez que se ha realizado el requerimiento de pago y no en el momento de la admisión de la petición inicial del juicio monitorio. Así, si se comprueba después de la petición inicial que el domicilio del deudor no es el consignado en la misma, no se produce la perpetuatio jurisdictionis, sino que es posible que el juzgado que admitió la petición monitoria se inhiba. No se puede olvidar que la petición se admitió precisamente porque el domicilio facilitado por el acreedor estaba ubicado en la sede de ese órgano judicial y, una vez constatado en el momento del requerimiento de pago, que el deudor tiene su domicilio en otro partido judicial distinto, el recurso al auxilio judicial no debe admitirse pues el objetivo perseguido por el fuero imperativo del art. 813.1 LEC es facilitar el requerimiento de pago y las posibles actitudes defensivas del deudor frente al mismo.

Ahora bien, la jurisprudencia mayoritaria, en concreto del Tribunal Supremo, dio una solución distinta al problema anterior dependiendo de si el cambio de domicilio se produjo antes o después de la admisión de la petición 
inicial del monitorio. En el primer caso ${ }^{40}$ como señala el ATS de 23 de febrero de 2006 "cuando el cambio de domicilio haya tenido lugar antes de la iniciación del proceso, aunque se constate después, no se está en el caso del art. 411 LEC que vincula la perpetuación de la jurisdicción a la litispendencia y, por ende, a la interposición de la demanda, una vez admitida (art. 410 de la misma Ley), así como que, en tal supuesto, cabe que el Juzgado que admitió la petición inicial, por considerarse competente a la vista del domicilio atribuido en ella al deudor (art. 813 LEC) se inhiba cuando tenga noticia del error en la designación o de que su cambio se produjo con anterioridad al comienzo de la litispendencia". ${ }^{41}$

Por el contrario, en el segundo supuesto, cuando ese cambio de domicilio o residencia se produzca una vez que el órgano ante el que se presentó la petición inicial ha declarado su propia competencia, esto es, después de la admisión de esa petición, ya no cabe la modificación de la competencia por aplicación del art. 411 LEC. $^{42}$

Esta doctrina jurisprudencial, que permitía la inhibición del órgano jurisprudencial una vez constatada la imposibilidad de realizar el requerimiento de pago en el domicilio fijado en la petición inicial, dio lugar en muchas ocasiones a un efecto no deseado en cuando la remisión de los autos al órgano considerado competente podía provocar una nueva declaración de incompetencia; con ello, se iniciaba en muchas ocasiones un periplo de las actuaciones de un juzgado a otro de distintas localidades, de tal forma que la pretendida rapidez y agilidad del juicio monitorio quedaba en entredicho.

Esta situación intentó ser solventada por el Tribunal Supremo mediante el Auto de 5 de enero de 2010 en la que aplica la doctrina relativa al denominado "deudor volátil" que supone que si no es localizado el deudor en el domicilio que consta en la petición inicial, no resulta de aplicación el art. 58 LEC y las sucesivas

\footnotetext{
$40 \mathrm{Al}$ que se equipara también el supuesto en que el acreedor consigna un domicilio que no coincide con la realidad, pese a no haberse realizado ningún cambio por parte del deudor.

${ }^{41}$ ATS de 23 de febrero de 2006 (PROV 2006/139528).

Igualmente, AATS de 27 de octubre de 2004 (PROV 2005/33259); 14 de enero de 2005 (PROV 2005/88747), 17 de febrero de 2005 (RJ 2005/2436), 28 de febrero de 2005 (PROV 2005/219558); 14 de marzo de 2005 (RJ 2005/3696).

42 AATS de 25 de noviembre de 2002 (PROV 2002/266397); 22 de diciembre de 2003 (RJ 2004/733); 26 de junio de 2004 (RJ 2004/4624); 10 de junio de 2004 (PROV 2004/183162).

Es muy significativo el AAP de Valencia, de 1 de febrero de 2010 (AC 2010/495) cuando señala que "para que resulte competente un juzgado diferente a aquel que conoció de la petición inicial es necesario acreditar que el domicilio actual conocido por hecho sobrevenidos ya era real en el momento en que se presentó la petición, no siéndolo por esta razón el que fue facilitado por la parte actora; en consecuencia, el carácter imperativo de las normas de competencia territorial ex artículos 813 y 48 LEC supondrían la no aplicación del principio de la perpetuación de jurisdicción (art. 411). Por el contrario, si no se acredita tal circunstancia, o si resulta probado que la alteración se produjo a posteriori, el juzgado que conoció inicialmente perpetúa su jurisdicción por aplicación del artículo 411, aunque el requerimiento de pago deba practicarse en el nuevo domicilio acudiendo al auxilio judicial".
} 
González - El juicio monitorio en España tras las últimas reformas procesales

cadenas de inhibiciones, sino que: "Lo procedente será el archivo de las actuaciones con devolución al acreedor de la documentación aportada para que, si ello interesa a su derecho, pueda iniciarlo de nuevo en el lugar que considere oportuno o acudir directamente al proceso declarativo, solución aplicable con carácter general al proceso monitorio". ${ }^{43}$

Pues bien, esta es la línea seguida por la Ley 4/2011 con el nuevo apartado incluido en el art. 813 LEC que señala que "Si, tras la realización de las

43 ATS de 5 de enero de 2010 (RJ 2010/410). El sentido de esta nueva doctrina jurisprudencial queda muy bien reflejada en las siguientes palabras del citado auto: "Pues bien, en la práctica sucede con frecuencia que no se llega a conocer en ningún momento cuál es el Juzgado territorialmente competente puesto que el deudor no es localizado. Las opuestas soluciones que caben frente a ello oscilan entre, por un lado, la perpetuación de las actuaciones con sucesivos traslados de un Juzgado a otro intentando averiguar el domicilio o residencia del deudor para, en caso negativo, mantener indefinidamente abiertas las actuaciones a voluntad del acreedor; y por otro -la que ahora se estima más adecuada- entender que cuando el Juzgado ante el que se presenta la solicitud admite la pretensión y se declara competente territorialmente -por aplicación de lo dispuesto en el artículo 813 de la LEC- no está fijando indebidamente su competencia, aun cuando se haya determinado erróneamente el lugar donde se encuentra el deudor, sino que tal declaración de competencia territorial es correcta en atención a los datos contenidos en la petición, que resultan esenciales para la apertura del procedimiento. En tal caso de falta de localización del deudor en el domicilio señalado, cabe incluso admitir con la regulación actual que se intente una primera averiguación de domicilio de modo que si aparece otro distinto al suministrado, pero dentro del propio partido judicial, se intente el requerimiento; pero si tampoco éste resulta efectivo o el domicilio averiguado pertenece a distinto partido judicial no habrá de ponerse en marcha el mecanismo previsto en el artículo 58 de la Ley Procesal para negar ahora una competencia territorial que ya se declaró correctamente conforme a la ley, sino que lo procedente será el archivo de las actuaciones con devolución al acreedor de la documentación aportada para que, si ello interesa a su derecho, pueda iniciarlo de nuevo en el lugar que considere oportuno o acudir directamente al proceso declarativo; solución aplicable con carácter general al proceso monitorio, salvo el caso distinto de las deudas derivadas del régimen de propiedad horizontal que, conforme a lo dispuesto en el artículo 815.2 de la Ley de Enjuiciamiento Civil, tiene un régimen especial en cuanto a la localización del deudor.

Dicha solución resulta, además, acorde con la nueva redacción que la Ley 13/2009, de 3 de noviembre, de reforma de la legislación procesal para la implantación de la nueva oficina judicial - cuya entrada en vigor se producirá el día 5 de mayo de 2010- da al apartado 1 del artículo 815 de la Ley de Enjuiciamiento Civil, al disponer en su párrafo primero que «si los documentos aportados con la petición fueran de los previstos en el apartado 2 del artículo 812 o constituyeren un principio de prueba del derecho del peticionario, confirmado por lo que se exponga en aquélla, el Secretario judicial requerirá al deudor para que, en el plazo de veinte días, pague al peticionario, acreditándolo ante el Tribunal, o comparezca ante éste y alegue sucintamente, en escrito de oposición, las razones por las que, a su entender, no debe, en todo o en parte, la cantidad reclamada. En caso contrario dará cuenta al Juez para que resuelva lo que corresponda sobre la admisión a trámite de la petición inicial». De ello se desprende que la intervención del Juez se producirá una vez que se conozca si el deudor ha sido encontrado en el lugar señalado por el acreedor; siendo así que, en caso de no haber podido ser localizado, el Juez podrá declarar la no admisión a trámite de la petición inicial al no poder ser sustanciado ante él el proceso."

En similar sentido, AATS de 2 de marzo de 2010 (RJ 2010/2324 y RJ 2010/2325); de 6 de abril de 2010 (RJ 2010/2545). 
correspondientes averiguaciones por el secretario Judicial sobre el domicilio o residencia, éstas son infructuosas o el deudor es localizado en otro partido judicial, el juez dictará auto dando por terminado el proceso, haciendo constar tal circunstancia y reservando al acreedor el derecho a instar de nuevo el proceso ante el Juzgado competente".

\section{b) Modificaciones en materia de petición inicial}

Como ya se apuntó, ${ }^{44}$ tras la reforma del art. 815 LEC operada por la Ley 13/2009, la admisión de la petición inicial del juicio monitorio es una competencia que, en cuanto actividad reglada, corresponde al Secretario judicial, quien ante cualquier duda sobre su inadmisión, deberá dar cuenta al juez para que decida a través de auto sobre su admisión o rechazo.

En esta misma línea y como una concreción de la previsión general, la Ley 4/2011 introduce un nuevo apartado en el art. 815 LEC en los siguientes términos: “3. Si de la documentación aportada con la petición se desprende que la cantidad reclamada no es correcta, el Secretario judicial dará traslado al juez, quien, en su caso, mediante auto podrá plantear al peticionario aceptar o rechazar una propuesta de requerimiento de pago por el importe inferior al inicialmente solicitado que especifique.

En la propuesta, se deberá informar al peticionario de que, si en un plazo no superior a diez días no envía la respuesta o la misma es de rechazo, se le tendrá por desistido". ${ }^{4}$

Debe tenerse en cuenta que el control que realiza el Secretario judicial viene determinado por "la documentación presentada" por el acreedor lo que supone que el mismo debe limitarse a un control estrictamente formal sin que en

\footnotetext{
${ }^{44}$ Vid. apartado 2 a).

${ }^{45}$ Esta previsión tiene su origen en el art. 10 Reglamento (CE) No 1896/2006 por el que se crea un juicio monitorio europeo y que además obligó a la introducción por la misma Ley 4/2011 de una disposición adicional 23 en la LEC para facilitar la aplicación en España del procedimiento comunitario. En concreto, el apartado 4 de la citada disposición adicional señala que "4. Si los requisitos establecidos en los artículos 2, 3, 4, 6 y 7 del Reglamento (CE) No 1896/2006 se dan únicamente respecto de una parte de la petición, el secretario judicial dará traslado al juez, quien, en su caso, mediante auto y en la forma prevista en el formulario C del anexo III planteará al demandante aceptar o rechazar una propuesta de requerimiento europeo de pago por el importe que especifique, de acuerdo con lo dispuesto en el artículo 10 del citado Reglamento.

En la propuesta se deberá informar al demandante de que, si no envía la respuesta o la misma es de rechazo, se desestimará íntegramente la petición del requerimiento europeo de pago, sin perjuicio de la posibilidad de formular la reclamación del crédito a través del juicio que corresponda con arreglo a las normas procesales nacionales o comunitarias.

El demandante responderá devolviendo el formulario $C$ enviado en el plazo que se haya especificado. Si se acepta la propuesta de requerimiento europeo de pago parcial, la parte restante del crédito inicial podrá ser reclamada a través del juicio que corresponda con arreglo a las normas procesales nacionales o comunitarias".
} 
González - El juicio monitorio en España tras las últimas reformas procesales

ningún caso pueda entrar en la cuestión de fondo; esto es, el Secretario judicial no podrá sustituir el control que debe realizar el deudor demandado a través de su escrito de oposición. ${ }^{46}$

Como consecuencia de lo anterior, el Secretario judicial únicamente podría controlar que existe un error aritmético en la petición inicial, esto es, que del documento o documentos presentados se deriva que la cuantía de la deuda no es la que figura en la misma; o que la cantidad que se reclama es superior a la que se puede exigir a través de este procedimiento, en aquellos casos en que se trata de una deuda basada en varios documentos y unos se consideran idóneos para contener una deuda monitoria y otros no. Antes de la modificación operada por la Ley 37/2011 de 10 de octubre, de medidas de agilización procesal, que se analizará en el apartado siguiente, una de las situaciones que sí debía ser controlada por el Secretario judicial era que la cuantía de la deuda monitoria no superaba la cantidad establecida en el art. 812 LEC, esto es, los 250.000 euros. No obstante, actualmente, tras la citada reforma que, como se expondrá en el apartado dedicado a la misma, ha eliminado el límite cuantitativo del juicio monitorio, ya no procede ningún tipo de control al respecto.

Dada cuenta al Juez por parte del Secretario judicial del error en la cuantía de la deuda, el mismo a través de auto, le planteará al acreedor la posibilidad de aceptar que se requiera al deudor de pago por una cantidad inferior a la inicialmente solicitada que especifique. Esto es lo verdaderamente relevante de la reforma, que el Juez en lugar de inadmitir sin más la petición inicial dé al acreedor la opción de subsanar ese defecto y reducir la cuantía de la reclamación y, por tanto, la cantidad requerida al deudor. No obstante, el precepto deja algunas cuestiones sin aclarar de una gran incidencia práctica; así el efecto que tiene para el acreedor aceptar el requerimiento de pago al deudor por una cantidad inferior a la inicialmente reclamada en su petición inicial en cuanto esto podría entenderse como una renuncia a la cantidad restante de la deuda. Sin duda, habría sido conveniente que el legislador hubiera incluido en el nuevo apdo. 3 del art. 815 LEC una previsión relativa a la posibilidad del acreedor de reclamar esa cantidad posteriormente a través del procedimiento que corresponda. ${ }^{47}$

\section{c) Pago de tasa judicial en el juicio monitorio}

La Ley 53/2002, de Medidas Fiscales, Administrativas y del Orden Social, de 30 de diciembre de 2002 reintrodujo en el ordenamiento jurídico español, en su art. 35,

\footnotetext{
${ }^{46}$ El Secretario judicial no podrá, por tanto, dar traslado al Juez sus dudas sobre la admisión de la petición porque considere que se trata de un supuesto de pluspetición puesto que ésta es una cuestión de fondo que deberá alegar el deudor en su escrito de oposición.

${ }^{47}$ QUILEZ MORENO, José María, El proceso monitorio: estudio doctrinal, jurisprudencia y futura reforma de la e-Justicia (nota 36), pp. 102 y ss.
} 
la "Tasa por el ejercicio de la potestad jurisdiccional en los órdenes civil y contencioso administrativo". 48

El hecho imponible de esta tasa viene determinado por el ejercicio de la actividad jurisdiccional por algunas personas jurídicas ${ }^{49}$ en los ámbitos civil, y contencioso administrativo, cuando realizan las actividades que el propio art. 35 Ley 53/2002, entre ellas, la interposición de la demanda en toda clase de procesos declarativos y de ejecución civiles. La mencionada Ley fue desarrollada por la Orden HAC/661/2003, de 24 de marzo, por la que se aprueba el modelo de autoliquidación de la tasa por el ejercicio de la potestad jurisdiccional en los órdenes civil y contencioso-administrativo y se determinan el lugar, la forma y los plazos para su presentación; además esta Orden del Ministerio de Hacienda delimita el contenido de la Ley y su efectivo alcance.

En lo que aquí interesa, la Orden HAC 661/2003 declaraba exento el juicio monitorio del pago de la tasa, pues sólo exigía la tributación cuando, formulada oposición por el deudor, se siguiera el trámite del juicio ordinario correspondiente por la cuantía.

Frente a esta situación, la Ley 4/2011, modifica el art. 35 Ley 53/2002, incluyendo como nuevo hecho imponible de la tasa judicial la presentación de la petición inicial del juicio monitorio. ${ }^{50}$ Además, esta medida se completa con la exclusión de la obligación de pago de la tasa por el inicio del juicio declarativo correspondiente por la cuantía que tiene lugar ante la oposición del deudor en el juicio monitorio, que se exigía en la redacción anterior de la Ley 53/2002, con el objetivo de evitar la doble imposición por un mismo hecho.

La modificación introducida por la Ley 4/2011, trata de poner fin a dos problemas de muy diferente índole; de un lado, se igualan las condiciones económicas de acceso al juicio monitorio español y al previsto para el ámbito de la Unión Europea en cuanto el Reglamento (CE) 1896/2006 del Parlamento Europeo y del Consejo, de 12 de diciembre de 2006, por el que se establece un proceso monitorio europeo que, tanto en su considerando 12 como en su art. 25, hace referencia a la necesidad del establecimiento de una tasa para la presentación inicial de este procedimiento. Con esta modificación la tasa judicial deberá ser

\footnotetext{
${ }^{48}$ La Ley 37/2011, de 10 de octubre, de medidas de agilización procesal, modifica el art. 35 de la Ley 53/2002 actualizando las cuantías de las tasas en los Órdenes Civil y ContenciosoAdministrativo.

49 Están obligadas al pago de la tasa judicial únicamente las personas jurídicas que tienen una determinada capacidad económica; en concreto, las sometidas al impuesto sobre sociedades por un volumen de negocio neto durante el año anterior superior a 6 millones de euros.

${ }^{50}$ Así como la petición inicial del juicio monitorio europeo.

En concreto, se añade un nuevo apdo. $\mathrm{f}$ al art. 35 Ley 53/2002: "El devengo de la tasa se produce, en el orden jurisdiccional civil, en los siguientes momentos procesales:... f) presentación inicial del procedimiento monitorio y del proceso monitorio europeo".
} 
González - El juicio monitorio en España tras las últimas reformas procesales

pagada tanto si se inicia un juicio monitorio de los arts. 812 y ss. LEC, como ante un litigio transfronterizo, un monitorio europeo.

De otro lado, trata de resolverse un problema que se estaba produciendo en la práctica en nuestros tribunales, pues se estaba acudiendo por parte de los operadores jurídicos de forma habitual al juicio monitorio en lugar de otro procedimiento especial por el simple hecho de que el primero no estaba gravado con la tasa judicial. Un ejemplo ilustra perfectamente la situación; a saber, el poseedor de un título cambiario (letra de cambio, cheque o pagaré) en lugar de acudir al procedimiento específico previsto en los art. 819 y ss. LEC (cuya iniciación está gravada con la tasa judicial), utilizaba el juicio monitorio para la reclamación de su deuda en cuanto el título cambiario cumple las exigencias documentales que requiere el mismo en su art. 812 LEC. $^{51}$

En la misma línea que el supuesto anterior, en la práctica judicial también suele darse con frecuencia la admisión como documento acreditativo de la deuda monitoria de títulos de ejecución extrajudiciales (art. 517 LEC), como por ejemplo, créditos documentados en pólizas o contratos de préstamo intervenidos por fedatarios públicos, en lugar de acudir al procedimiento de ejecución de título no judicial.

En ambos casos, los operadores jurídicos acudían al juicio monitorio ante el ahorro de costes que suponía no tener que pagar la tasa judicial en el juicio monitorio. Habrá de esperarse un tiempo para conocer si efectivamente esta modificación que unifica el tratamiento fiscal del juicio monitorio a otros procedimientos civiles, tiene el efecto pretendido.

\section{Reforma de la Ley 37/2011, de 10 de octubre}

La Exposición de Motivos de la Ley 37/2011, de 10 de octubre, de medidas de agilización procesal, parte del reconocimiento constitucional a todas las personas del derecho a la tutela judicial efectiva contenido en el art. 24 CE para poner de manifiesto la necesidad de introducir profundas reformas para asegurar la sostenibilidad del sistema y garantizar que todos los ciudadanos puedan disponer de un servicio público de calidad ante la constatación del aumento de litigiosidad

\footnotetext{
51 En lo que respecta a la jurisprudencia, con carácter general admite la posibilidad de acudir al juicio monitorio al tenedor de una letra de cambio cheque o pagaré en cuanto reconoce el derecho que tiene el mismo a optar entre aquel cauce procedimental que mejor se adapte a sus intereses al no existir ninguna norma que "le obligue imperativamente a acudir al juicio especial, esto es, al cambiario" (AAP de Sevilla, de 8 de junio de 2004).

En igual sentido, AAP de Madrid, de 19 de febrero de 2009 (AC 2009/1213); de Madrid, de 1 de julio de 2008 (PORV 2009/364110); de Islas Baleares, de 1 de febrero de 2005 (JUR 2005/75350); de Madrid, de 14 de septiembre de 2004 (JUR 2004/264473); de Toledo, de 20 de febrero de 2002 (AC 2002/556).
} 
producido en todos los ámbitos del ordenamiento jurídico, y muy especialmente en el civil.

La Ley 37/2011 continúa la línea de reformas procesales iniciada con la LO $1 / 2009$, de 3 de noviembre, complementaria de la Ley 13/2009, de la misma fecha, de reforma de la legislación procesal para la implantación de la nueva Oficina judicial. Se trata de introducir en la legislación procesal mejoras que permitan agilizar los distintos procedimientos, sin merma de las garantías para el justiciable. En concreto, en el orden jurisdiccional civil, se incluyen toda una serie de modificación en la LEC que obedecen al propósito común de suministrar a nuestros tribunales instrumentos procesales óptimos para la gestión procesal.

En lo que aquí interesa, trata el legislador de optimizar el juicio monitorio y como expresamente señala la Exposición de Motivos de la Ley "suprime el límite cuantitativo del mismo, equiparándolo de este modo al proceso monitorio europeo, con el fin de evitar limitaciones de acceso a este procedimiento, que se ha convertido con mucho en la forma más frecuente de iniciar las reclamaciones judiciales de cantidad." 52

Con esta modificación, el art. 812.1 LEC señala que "Podrá acudir al proceso monitorio quien pretenda de otro el pago de deuda dineraria de cualquier importe"; con esta previsión, se atienden las reiteradas voces de la doctrina procesalista que llevaba tiempo abogando por la necesaria eliminación de la cuantía en la línea de lo establecido en el ámbito europeo.

Como se apuntó, la eliminación de ese límite cuantitativo resuelve el problema planteado en la práctica forense cuando un acreedor fraccionaba la deuda con el objetivo de no superar la cuantía máxima de reclamación que permitía la ley procesal. Ese fraccionamiento de la deuda monitoria a efectos de no incumplir el requisito del límite cuantitativo previsto en el art. 812.1 LEC (en su redacción anterior a la Ley 37/2011), podía considerarse un fraude procesal provocado por el acreedor.

Ahora bien, no se debe perder de vista la dificultad con que se encontraba el Secretario judicial para decidir sobre la admisión de una petición monitoria ante un posible fraccionamiento de la deuda por el acreedor puesto que se daban situaciones en que el acreedor podía justificar la discrepancia entre la deuda existente realmente y la que efectivamente reclamaba en su petición. Pensemos, por ejemplo, en la existencia de documentos individuales que reflejan una deuda única o el supuesto de deuda con distintos plazos de vencimiento. Estas situaciones podían ser solventadas en muchas ocasiones con la facultad atribuida al Secretario judicial y al Juez por el nuevo apartado 3 del art. 815 LEC (introducido por la Ley 13/2009, como ya se apuntó) de plantear al demandante si aceptaba una propuesta de requerimiento de pago por importe inferior al solicitado en su

\footnotetext{
52 Apartado III Exposición de Motivos Ley 37/2011.
} 
González - El juicio monitorio en España tras las últimas reformas procesales

petición inicial. No obstante, en muchas ocasiones será solamente a través de la oposición del deudor cuando se pueda detectar que el acreedor ha fraccionado la deuda monitoria a efectos de poder utilizar el juicio monitorio en lugar del ordinario que corresponda por la cuantía.

Pero la reforma operada por la Ley 37/2011 no sólo elimina del art. 812.1 LEC la referencia a la cuantía, sino que, en relación a los requisitos que debe cumplir la deuda dineraria para su tramitación a través del juicio monitorio, añade, a los ya previstos en la redacción anterior (esto es, que la deuda sea vencida, exigible y de cantidad determinada), que sea líquida.

En principio, la referencia a la liquidez no parece añadir nada nuevo frente a la previsión anterior, que aludía, como se ha expuesto a que la cantidad solicitada por el acreedor sea determinada, puesto que deuda líquida y determinada parecen tener un mismo significado. Muestra de ello es que el artículo 572 LEC, dentro de Título referente a la ejecución dineraria, define como líquida a "toda cantidad de dinero determinada, que se exprese en el título con letras, cifras o guarismos comprensibles".

La necesidad de que el acreedor fije en su petición la cantidad concreta y precisa que reclama al demandado es esencial para garantizar la agilidad propia del juicio monitorio, puesto que el Secretario judicial podrá de forma inmediata requerir de pago al deudor. Ahora bien, la referencia a que la deuda sea líquida no debería excluir, como estaba ocurriendo antes de su modificación operada por la Ley 37/2011, aquellos supuestos en que la cantidad no viene fijada de forma concreta en la petición inicial pero basta con una simple operación aritmética para su concreción. Especialmente claro a este respecto es el AAP de Madrid de 13 de enero de 2004 cuando señala que "para que pueda despacharse el procedimiento monitorio, es necesario que la deuda sea determinada; a tal efecto, la deuda de cantidad determinada es asimilable a deuda líquida y deuda líquida, tanto por la actual LEC como por la anterior (art. 921 LEC de 1881) y jurisprudencia interpretativa es también aquélla para cuya concreta determinación bastan simples operaciones aritméticas". ${ }^{33}$

Por el contrario, no podrá admitirse, en ningún caso, una petición monitoria cuya determinación exigiera una operación de liquidación realizada por el Juez, como es el caso de una deuda de valor o una compensación de daños y perjuicios.

${ }^{53}$ AAP de Madrid de 13 de enero de 2004 (JUR 2004/251760). 


\section{BIBLIOGRAFÍA}

* ARMenta DEU, Teresa: Lecciones de Derecho Procesal Civil, Ed. Marcial Pons, Madrid, 2004.

* BANACLOCHE PALAO, Julio: "El proyecto de Nueva Oficina Judicial: ¿hacia un nuevo proceso administrativizado?”, La Ley, núm. 7251, 2009, http:/ / www.laley.es.

* BANACLOCHE PALAO, Julio: Los Juzgados de lo Mercantil: régimen jurídico y problemas procesales que plantea su actual regulación, Ed. Civitas, Navarra, 2005.

* CORTÉS DOMíngueZ, Valentín: Derecho Procesal Civil. Parte Especial (con Moreno Catena), Ed. Tirant Lo Blanch, Valencia, 2008.

* GÓmeZ COLOMER, Juan Luis: Derecho Jurisdiccional II. Proceso Civil (con Montero Aroca, Montón Redondo y Barona Villar), Ed. Tirant Lo Blanch, Valencia, 2004.

* _Comentarios prácticos a los arts. 812 a 818 del Capítulo I del Título IV de la Ley de Enjuiciamiento Civil: del proceso monitorio”, en Ejecución judicial de titulos extrajudiciales. Juicio cambiario y monitorio, Estudios de Derecho Judicial, núm. 69, 2005.

* GONZÁlEZ PILLADO, Esther: "La competencia objetiva en materia no concursal de los Juzgados de lo Mercantil: problemas procesales", en Anuario de la Facultad de Derecho de Ourense, 2006.

* _Comentario a la SAP, de Ourense (Sección 1ª), del 20 de Julio del 2010. La oposición del deudor en el juicio monitorio y su conexión con el proceso ordinario posterior", en Revista Xurídica Galega, núm. 67, 2010.

* Herrero perezaguA, Juan F.: "La reforma del proceso monitorio por la Ley 13/2009”, BIB 2010/1685, http://ww.weslaw.es.

* Magro Servet, Vicente: El proceso monitorio, Ed. Sepín, Madrid, 2006.

* NAVARro RODRÍGUEZ, Sonia: "Reformas procesales contra la morosidad", Diario La Ley, núm. 7568, 2011, http://www.laley.es.

* RODRíguez ACHÚtEgui, Edmundo: "De nuevo sobre las dudas del proceso monitorio en el Juzgado Mercantil”, BIB 2010/1502, http://www.westlaw.es.

* QUÍlEZ ROMERO, José $\mathrm{M}^{\mathrm{a}}$.: El proceso monitorio: estudio doctrinal, jurisprudencial y futura realidad de la e-Justicia, Ed. La Ley, Madrid, 2011. 